\title{
Influence of aluminium and niobium alloying on phase composition, structure and properties of heat- and wear-resistant cast iron of Cr-Mn-Ni-Ti system
}

\author{
V. M. Kolokoltsev, Dr. Eng., Prof. ${ }^{1}$ \\ E.V.Petrochenko, Dr. Eng., Prof. ${ }^{1}$, e-mail: evp3738@mail.ru \\ O.S. Molochkova, Cand. Eng., Associate Prof. ${ }^{1}$, e-mail: opetrochenko@mail.ru
}

\section{${ }^{1}$ Nosov Magnitogorsk State Technical University, Magnitogorsk, Russia}

\begin{abstract}
The paper presents the data on phase composition and structure forming for the alloys and oxide layers, on distribution of elements among the alloy structural components and oxidation surface through the depth of oxide and sub-oxide layers, on variation of wear resistance, scale resistance, growing stability and mechanical properties of cast iron of $\mathrm{Cr}-\mathrm{Mn}-\mathrm{Ni}-\mathrm{Ti}-\mathrm{Al}-\mathrm{Nb}$ system depending on different aluminium and niobium content and thermal accumulating capacity of a casting mould. Complex carbides $(\mathrm{Nb}, \mathrm{Ti}) \mathrm{C}$ are forming in white cast iron during niobium alloying. Quantitative metallographic analysis of $(\mathrm{Nb}, \mathrm{Ti}) \mathrm{C}$ carbides and $(\mathrm{Cr}, \mathrm{Fe}, \mathrm{Mn})_{7} \mathrm{C}_{3}$ complex carbides was carried out on the samples with examined composition. The tests for scale resistance were conducted, structure and properties of cast iron were investigated. It was determined that chemical composition and structure of oxide layers depend on distribution of alloying elements among the alloy structural components. It was established that the areas of oxide film surface layer, which were formed on eutectics, contain mainly manganese; its concentration is more than $65 \%$, while $\mathrm{Al}$ is $4 \%$ and $\mathrm{Cr}$ is $1 \%$. Manganese leads to increase of defects amount, such as pores, micro-cracks and vacancies, in oxide film during high-temperature gas oxidation; penetration ability of this film also increases, what has a negative effect on metal resistance to further destruction caused by oxidation. The film becomes porous, its thickness enlarges. Aluminium provides favourable influence on forming of the thin protective spinel-type films (dense substance with good metal adhesion) with minimal amount of defects; diffusion through such oxide film is very difficult. The areas of oxide layer, which were formed on austenite dendrites, contain mainly aluminium; its concentration is more than $24 \%$, while $\mathrm{Mn}$ is $16 \%$ and $\mathrm{Cr}$ is $12 \%$. High aluminium content provides small film thickness.

Joint alloying by aluminium and niobium leads to simultaneous increase of heat resistance and wear resistance. Wear resistance increased as a result of enlargement of the part of primary carbides $(\mathrm{Nb}, \mathrm{Ti}) \mathrm{C}$ with high hardness in the structure of cast iron. Composition of oxide films includes aluminium which strengthens their protective properties and rises of the alloy scale resistance. Alloying by niobium leads to secondary hardening during cooling in a casting mould. Dispersion particles of $\mathrm{M}_{7} \mathrm{C}_{3}$ carbides are forming in solid state, thereby no structure degradation occurs during testing at increased temperatures, and growing stability rises.
\end{abstract}

Key words: white cast iron, temperature conditions of metal cooling, casting moulds, chemical composition, cast iron structure, oxide layers, phase composition, dispersion hardening, heat resistance, wear resistance, microhardness.

DOI: $10.17580 /$ cisisr.2021.02.10

\section{Introduction}

Creation of the new multifunctional high-quality materials, which are characterized by combination of high mechanical, technological and operating properties, is one of the main problems of up-to-date material science. Practically all high-quality alloys, which are well-known at present time, are multi-component ones, thereby selection of their new chemical composition is possible on the base of thorough theoretical and experimental investigation of interaction of these components within the systems with complex alloying [1-4].

White complex alloyed cast iron is widely used for fabrication of the components of machines and mechanisms which are operating in abrasive media at normal and increased temperatures [5-9]. Resistance of such iron allows to increase service life of the components during operation without substantial impact loads by $3-15$ times in comparison with carbon steels, $110 \mathrm{G} 13 \mathrm{~L}$ type steels and other alloys [9], which are conventionally used in industrial production.

High-chromium complex alloyed white cast iron is one of the materials that can operate in complicated conditions; it is used in metallurgical and coke chemical industries, in mining and concentrating production, where stability of special properties in the aggressive environment at increased temperatures is required [10-13]. Its competitive market positions are based on its low production cost, absence of heat treatment and mechanical processing.

Alloying elements and variation of cooling speed during solidification of the alloys should provide a stable single-phase structure of metallic base with sufficient amount of strengthening phase, which will not be characterized by phase transformations during heating [14-21]. Thin solid protective oxide film will be also formed on the surface of

(c) Kolokoltsev V. M., Petrochenko E. V., Molochkova O. S., 2021 
components, ensuring combination of the required mechanical and operating properties.

The problems of additional alloying and modification, regulation of cooling speed during solidification of alloys (including steels and cast irons [22]) acquire especial importance; these aspects should provide the most favourable structural and phase state, as well as combination of the required properties.

Previous researches [23, 24] were devoted to examination of separate aluminium and niobium alloying, to influence of the temperature conditions of metal cooling in a casting mould on phase composition, mechanical properties, wear resistance and heat resistance of metal, as well as on protective properties, structure and chemical composition of oxide layers for cast iron of $\mathrm{Fe}-\mathrm{C}-\mathrm{Cr}-\mathrm{Mn}$-Ni-Ti system. It was shown that separate alloying of the examined cast iron grades by aluminium and niobium allowed to achieve simultaneously high values of heat resistance and wear resistance $[23,24]$. Aluminium increased substantially scale resistance of the researched alloys and not decreased wear resistance, while niobium enlarged wear resistance without any negative effect on scale resistance. That's why it is expedient to examine their joint influence on structure and properties of cast iron. The following tasks were formulated and solved in this work to achieve this aim.

1. Determination of influence features of chemical composition, temperature procedure of metal cooling in a casting mould on structure, morphology and chemical composition of phases as well as mechanical properties, wear resistance and heat resistance of alloyed cast iron.

2. Establishment of influence regularities of primary cast structure on protective properties, structure, chemical and phase composition of oxide layers in heat-resistant alloyed white cast iron.

3. Obtaining of mathematical relationships between microstructure properties and parameters and determination of numerical coefficient values and influence of microstructure parameters on cast iron properties.

4. Suggestion of compositions of heat- and wear-resistant cast iron grades having optimal special properties.

\section{Materials and techniques of investigation}

Investigations were conducted on the samples of complex alloyed white cast iron of the Fe-C-Cr-Mn-Ni-Ti-Al-Nb system. Aluminium and niobium content varied from 1.5 to $3.0 \%$. Alloys were molten in the IST-006 induction furnace with basic lining, then they were cast into various types of moulds - dry and wet sand-loam moulds (SLM) and block mould. Cooling speed in dry SLM was 3-10 grad/min within the crystallization interval, in wet SLM and in cast iron block mould made $8-12$ and up to $30 \mathrm{grad} / \mathrm{min}$ respectively.

Chemical composition of cast iron was determined using "Baird" emission spectrometer and OBLF QSG 750 spectrometer.

Structural and phase composition of different cast iron and oxide layers was examined via metallographic analysis (MEIL 2700 light microscope) and X-ray analysis. X-ray shooting was conducted using DRON-UM1 diffractometer (in cobalt K $\alpha$ emission). Quantitative metallographic analysis and automatic processing of microhardness measuring results were carried out via Thixomet PRO image analyzer [23, 24].

Chemical composition of phase components in the alloys and of oxidation surface was determined via scanning electronic microscopes “JEOL” JSM-6460 LV, "TESCAN VEGA II XMU” with X-ray probe microanalyzers. Distribution of chemical elements through the depth of oxide and suboxide layers was examined using glow discharge spectrometer.

Heat resistance was assessed by two parameters - scale resistance and growing stability, according to the GOST 6130-71 and 7769-82. Wear resistance testing of the alloys and cast iron grades for friction on abrasive particles (which are fixed not rigidly or half-fixed) was conducted according to the technique regulated by the GOST 23.208-79.

\section{Results of the research and discussion}

Investigations on joint influence of aluminium and niobium on operating and mechanical properties were conducted on ICh220Kh18G4NT cast iron. Nine chemical compositions were examined, each of them was cast in three types of casting moulds. Chemical composition of the researched alloys was within the following range (mass. \%): $2.1-2.61 \mathrm{C}$; 17.05-19.6 Cr; 3.0-5.87 Mn; 0.96-1.6 Ni; 0.43-1.65 Ti; $0.82-2.74 \mathrm{Al} ; 0.97-4.91 \mathrm{Nb}$.

Phase composition of cast iron presents $\alpha$-phase (ferrite), $\gamma$-phase (austenite), $\mathrm{M}_{7} \mathrm{C}_{3}$-type carbides and MC-type carbides. All researched cast iron grades were hypereutectic ones. After finishing of crystallization, the structure containing carbides $(\mathrm{Nb}, \mathrm{Ti}) \mathrm{C}$, excessive austenite dendrites and austenite chromium carbide eutectics as well as secondary $\mathrm{Cr}_{7} \mathrm{C}_{3}$-type carbides, is forming in all types of moulds.

Quantitative metallographic analysis of ( $\mathrm{Nb}, \mathrm{Ti}) \mathrm{C}$ carbides and $(\mathrm{Fe}, \mathrm{Cr}, \mathrm{Mn})_{7} \mathrm{C}_{3}$ complex carbides was carried out.

If $\mathrm{Al}$ content increases from 1 to $3 \%$ and $\mathrm{Nb}$ content remains permanent $1 \%$, volumetric part and square of austenite dendrites decreases from 60 to $53.5 \%$ and from 437 to $134 \mu \mathrm{m}^{2}$ respectively. $\mathrm{M}_{7} \mathrm{C}_{3}$-type carbides become more coarse: length and square of carbides increase from 2.0 to $3.6 \mu \mathrm{m}$ and from 4.3 to $6.9 \mu \mathrm{m}^{2}$ (for the samples cast in a dry sand-loam mould) as well as from 2.0 to $2.7 \mu \mathrm{m}$ and from 5.0 to $5.8 \mu \mathrm{m}^{2}$ (for the samples cast in a block mould). The distance between carbides lowers from 20 to 11 and from 11 to $8.7 \mu \mathrm{m}$ for cast iron which was cast in a dry sand-loam mould and in a block mould respectively. It was established that volumetric part of $\mathrm{M}_{7} \mathrm{C}_{3}$-type carbides rises from 14 to $21 \%$ for a dry sand-loam mould and from 17.4 to $22 \%$ for a block mould.

If $\mathrm{Nb}$ content increases from 1 to $3 \%$ and $\mathrm{Al}$ content makes $1 \%$, volumetric part of $\mathrm{M}_{7} \mathrm{C}_{3}$-type carbides decreases from 14.0 to $12.9 \%$ (for a dry sand-loam mould) and from 17.4 to $22 \%$ (for a block mould). $\mathrm{M}_{7} \mathrm{C}_{3}$-type carbides become more disperse: length and square of carbides decrease from 2.0 to $1.5 \mu \mathrm{m}$ and square of carbides decreases from 4.3 to 2.9 and from 5.0 to $2.3 \mu \mathrm{m}^{2}$ (for the samples cast in a dry sand-loam mould and in a block mould respectively). The 
distance between carbides lowers from 20 to 18 and from 11 to $8.9 \mu \mathrm{m}$ for cast iron which was cast in a dry sand-loam mould and in a block mould respectively. Amount of austenite dendrites increases from 53.5 до $57 \%$ for the samples with $2 \% \mathrm{Nb}$ to $63 \%$ in cast iron with $3 \% \mathrm{Nb}$, and square of austenite dendrites enlarges from 134 to 172 and up to $266 \mu \mathrm{m}^{2}$ respectively.

If $\mathrm{Nb}$ content increases from 1 to $3 \%$ and $\mathrm{Al}$ content makes $2 \%$, volumetric part of $(\mathrm{Nb}, \mathrm{Ti}) \mathrm{C}$ carbides rises from 2.5 to $5.5 \%$ (for a dry sand-loam mould) and from 3.0 to $5.2 \%$ (for a block mould). Volumetric part of chromium and manganese complex carbides increases from 8.2 to $15.0 \%$ (for a dry sand-loam mould) and from 9.3 to $22 \%$ (for a block mould) square of these carbides also increases and the distance between them lowers from 73 to 14 and from 27 to $6.9 \mu \mathrm{m}$ for a dry sand-loam mould and for a block mould respectively.

It was established, how hardness (HRC), microhardness of metallic base $\left(\mathrm{HV}_{\mathrm{bas}}\right)$ and eutectics $\left(\mathrm{HV}_{\mathrm{eut}}\right)$, wear resistance $\left(\mathrm{K}_{\mathrm{w}}\right)$, growing stability $(\mathrm{L})$ and scale resistance $\left(\Delta \mathrm{m}^{800}\right)$ vary depending on cooling conditions and chemical composition. It was revealed that cast iron ICh220Kh18G4Yu2B2NT, which is cast in a wet SLM, is characterized by optimal scale resistance. $4.9 \%$ of $(\mathrm{Nb}, \mathrm{Ti}) \mathrm{C}$ carbides and $12.2 \%$ of $(\mathrm{Fe}, \mathrm{Cr}, \mathrm{Mn})_{7} \mathrm{C}_{3}$ carbides formed in the cast iron structure. Niobium is considered as a strong carbide-forming element, it connects carbon in resistant

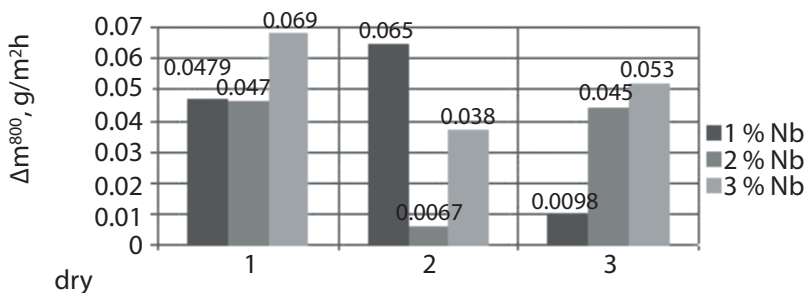

Content $\mathrm{Al}, \%$

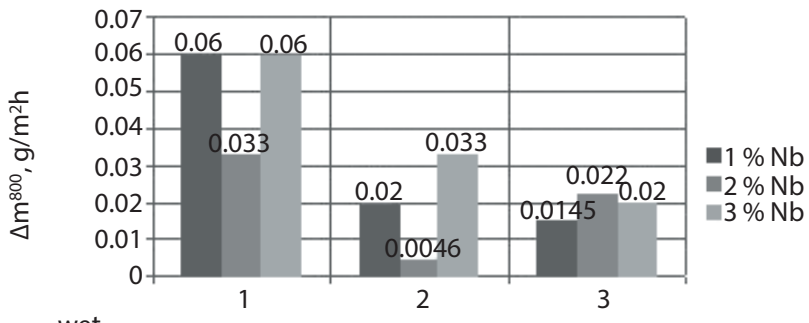

wet

Content $\mathrm{Al}, \%$

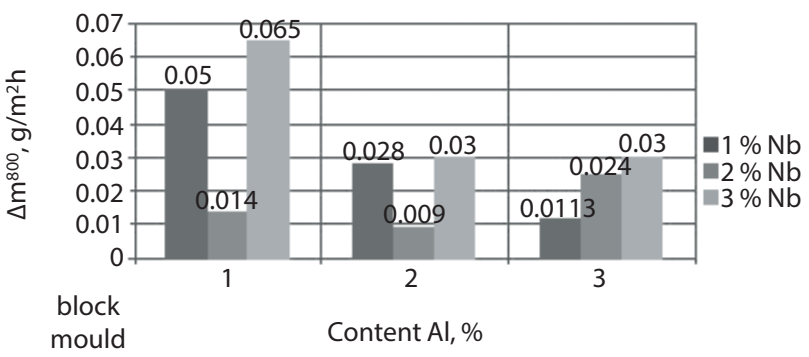

Fig. 1. Influence of chemical composition and cooling conditions on scale resistance of the alloys carbides, what leads to increase of chromium content in dendrites of metallic base; resistance to oxidation elevates. Increase of $\mathrm{Al}$ content with constant $\mathrm{Nb}$ content leads to rise of scale resistance of the alloys (Fig. 1).

If we rise the cooling speed, wear resistance coefficient increases from 4.99 to 5.4 units for the alloy containing $1 \% \mathrm{Al}$ and $1 \% \mathrm{Nb}$ (dry SLM and block mould), from 5.2 to 6.6 units for the alloys containing $2 \% \mathrm{Al}$ and $2 \% \mathrm{Nb}$, from 3.7 to 4.73 units for the alloys containing $3 \% \mathrm{Al}$ and $3 \% \mathrm{Nb}$; it is connected with enlargement of volumetric part of $\mathrm{M}_{7} \mathrm{C}_{3}$-type and $\mathrm{MC}$-type carbides. Rise of niobium amount in the alloy leads to increase of wear resistance, while rise of aluminium content decreases it slightly. Cast iron ICh220Kh18G4Yu2B2NT, which was cast in a block mould, is characterized by maximal wear resistance; approximately $5 \%$ of MC-type carbides and $14 \%$ of $\mathrm{M}_{7} \mathrm{C}_{3}$-type carbides are presented in the structure of such samples. This cast iron has maximal hardness $50 \mathrm{HRC}$ and eutectics microhardness 9,369 $\mathrm{MPa}$, what corresponds to the maximal value of eutectics microhardness for all examined alloys (Fig. 2).

If we vary $\mathrm{Al}$ and $\mathrm{Nb}$ content from 1 no $3 \%$ for each of them, hardness will vary slightly - from 46 to $50 \mathrm{HRC}$. Rise of Nb content from 1 to $3 \%$ leads to lowering of eutectics microhardness for cast iron, which was cast in a dry SLM, from 6.6 to 6.2 MPa (for the alloys with $1 \% \mathrm{Al}$ ), from 9.5 to $7.9 \mathrm{MPa}$ (for the alloys with $2 \% \mathrm{Al}$ ), and to elevation from 6.0 to $9.1 \mathrm{MPa}$ (for the alloys with $3 \% \mathrm{Al}$ ). Decrease of eutectics microhardness for the alloys with $\mathrm{Al}$ content 1 and $2 \%$ is connected with the fact, that $\mathrm{M}_{7} \mathrm{C}_{3}$-type carbide amount lowers in the alloys with increase of niobium
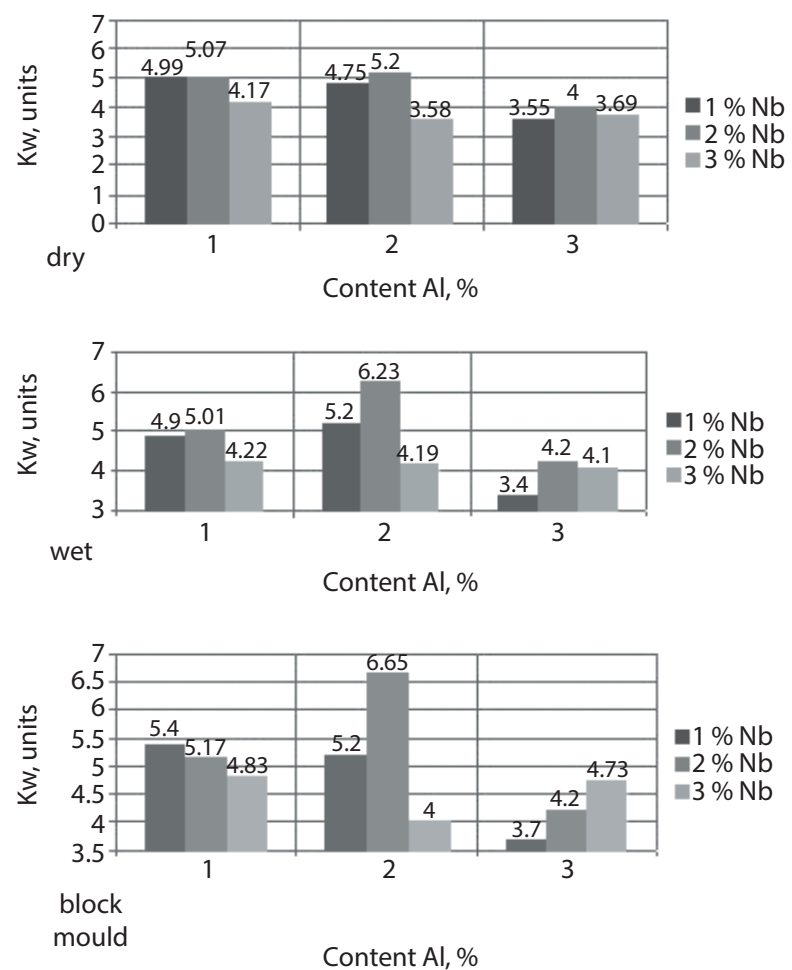

Fig. 2. Influence of chemical composition and cooling conditions on wear resistance coefficient of the alloys 
concentration. Elevation of $\mathrm{Al}$ content to $3 \%$ causes increase of its concentration both in austenite and in ferrite. At the same time, carbon concentration in the solid solution drops, what leads to increase of the volumetric part of $\mathrm{M}_{7} \mathrm{C}_{3}$-type carbides and rise of eutectics microhardness.

Heat- and wear resistant cast iron has the optimal operating properties at the following variation of its components (mass. \%): 2.1-2.2 C; 4.5-5.0 Mn; $18.0-19.0 \mathrm{Cr} ; 1.0-1.2 \mathrm{Ni}$; $0.4-0.6 \mathrm{Ti} ; 2.0 \mathrm{Nb} ; 2.0 \mathrm{Al}$.

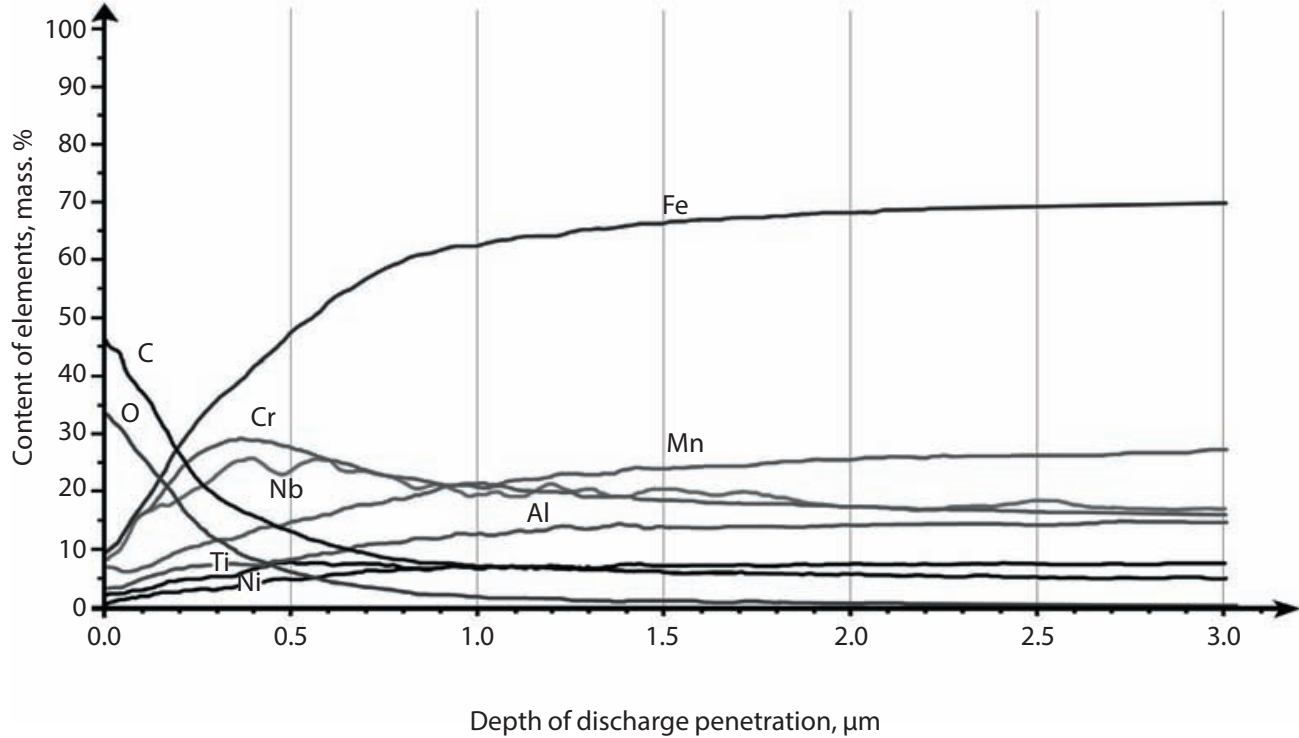

Fig. 3. Distribution of the elements through the depth of oxide layers
Joint alloying by aluminium and niobium promotes simultaneous increase of scale resistance, growing stability and wear resistance. Wear resistance rises due to increase of the part of $(\mathrm{Nb}, \mathrm{Ti})$ $\mathrm{C}$ carbide phase with high hardness. Aluminium is includ-

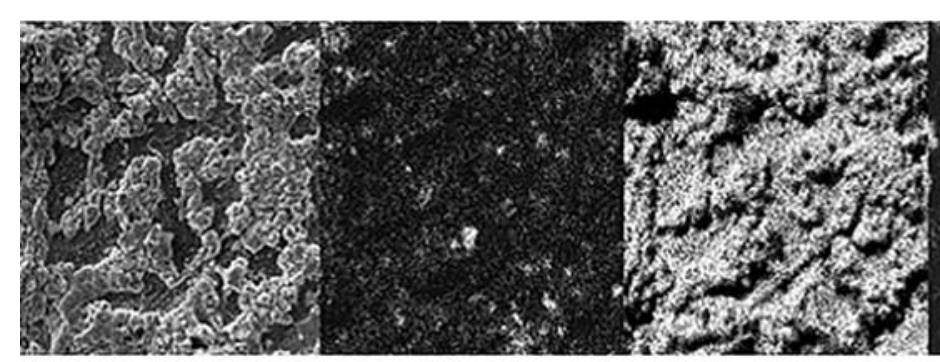

CKa1_2

O Ka1

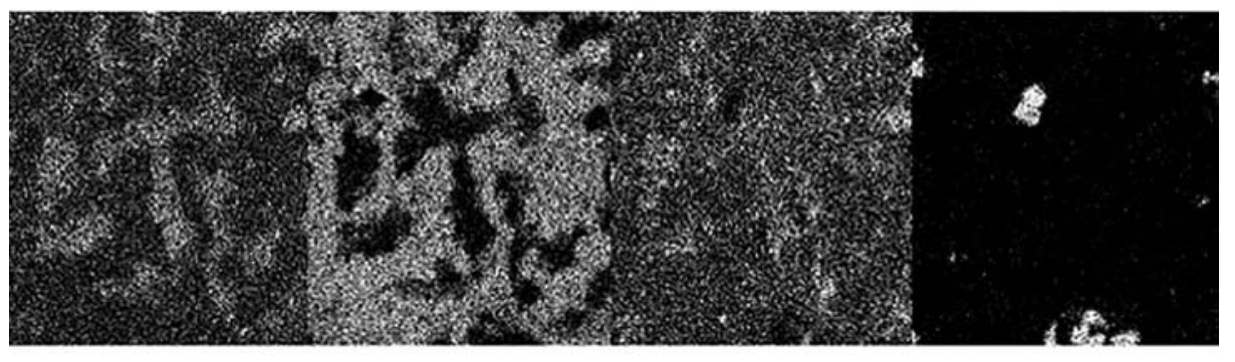

CrKa1

$\mathrm{Mn} \mathrm{Ka} 1$

Fe Ka1

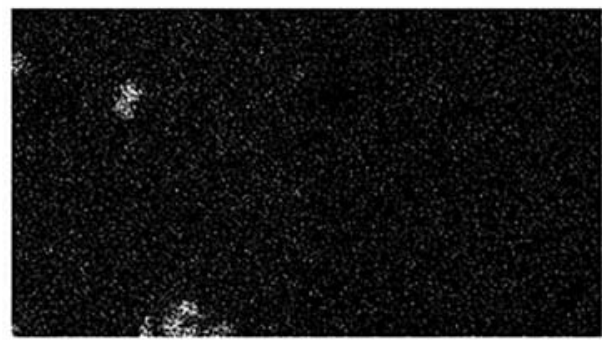

TiKa1

Ni Ka1

Fig. 4. Microphotograph of oxidized surface of cast iron ICh220Kh18G4Yu2B2NT and element-by-element plotting, $\mathbf{x 1 6 0 0}$
Al Ka1

$\mathrm{Nb}$ Ka1

ed in chemical composition of oxide films, their protective properties improve and, respectively, scale resistance of the alloy increases. Niobium alloying leads to secondary hardening in a casting mould; dispersion particles of $\mathrm{M}_{7} \mathrm{C}_{3}$ type carbides are forming during cooling in solid state; as a result, no structure degradation occurs at the working temperatures and growing stability improves.

The authors examined the chemical composition through the depth of oxide layers and local chemical composition of different areas of oxidized surface; distribution of the elements through the depth of oxide layers was determined (Fig. 3). It is shown that chromium is presented in the internal layers of forming oxide film with content to $30 \%$, manganese is presented in the amount to $1 \%$.

The method of X-ray plotting was used, concentration heterogeneities in various areas of oxide film were revealed (Fig. 4).

Distribution of the chemical elements in internal layers of oxide film was revealed via the method of local X-ray probe microanalysis (Fig. 5, Table).

Examination of the topography of cast iron oxidized surface displayed that oxide film contains two kinds of layers: dense thin layer ( $1^{\text {st }}$ type $)$ and 


\begin{tabular}{|c|c|c|c|c|c|c|c|c|}
\hline \multicolumn{9}{|c|}{$\begin{array}{l}\text { Local chemical composition of various areas of cast iron } \\
\text { ICh220Kh18G4Yu2B2NT oxide films and summarized spectrum }\end{array}$} \\
\hline \multirow{2}{*}{ Spectrum } & \multicolumn{8}{|c|}{ Content of the elements, \% } \\
\hline & C & 0 & Al & $\mathrm{Ti}$ & $\mathrm{Cr}$ & $\mathrm{Mn}$ & $\mathrm{Fe}$ & $\mathrm{Nb}$ \\
\hline Summarized & 6.07 & 24.14 & 6.84 & 0.28 & 4.62 & 45.18 & 8.84 & 1.31 \\
\hline $\begin{array}{l}\text { Spectrum } 1 \\
\text { (see Fig. 5) }\end{array}$ & 3.74 & 24.49 & 24.3 & - & 11.98 & 16.47 & 17.87 & 3.74 \\
\hline $\begin{array}{l}\text { Spectrum } 2 \\
\text { (see Fig. 5) }\end{array}$ & 3.45 & 25.72 & 4 & - & 1.16 & 65.82 & 3.85 & 3.45 \\
\hline
\end{tabular}

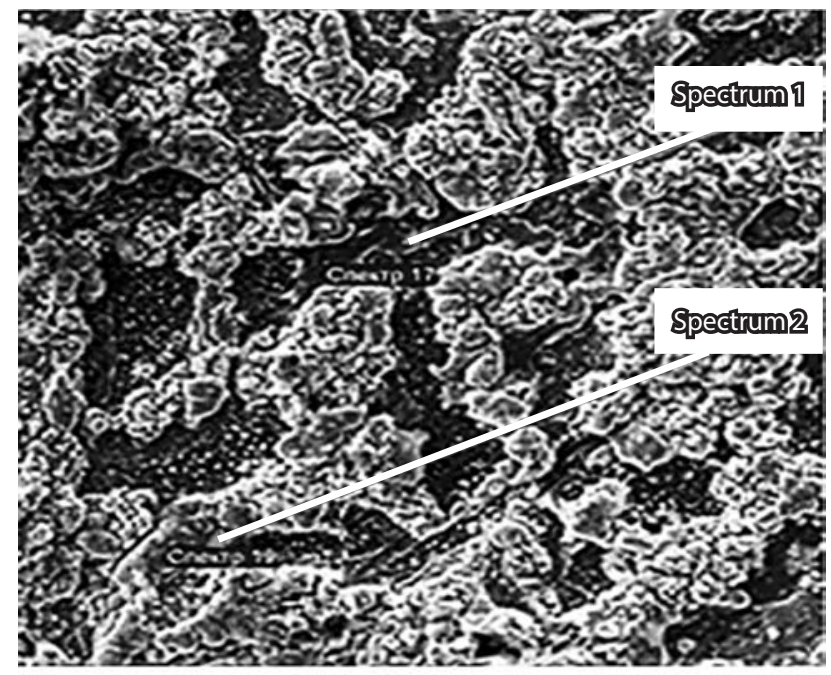

Fig. 5. Local chemical composition of various areas of oxide films, $\mathbf{x} 2000$

loose oxide layer ( $2^{\text {nd }}$ type $)$. Areas corresponding to austenite dendrites include more than $24 \% \mathrm{Al}$, about $16 \% \mathrm{Mn}$ and $12 \% \mathrm{Cr}$. Thereby the film, which was formed within these areas, is thin due to high aluminium content in it (1 ${ }^{\text {st }}$ type). Oxide-type surface ( $2^{\text {nd }}$ type), corresponding to eutectics areas, is enriched by $\mathrm{Mn}(65 \%), \mathrm{Al}$ (about $4 \%$ ) and $\mathrm{Cr}$ (about $1 \%$ ). Manganese rises penetration ability of oxide film, what decreases metal resistance to oxidation; in the areas which correspond to eutectics, the film is loose and its thickness increases [25]. Oxide films of both types contain niobium in the amount $3.4-3.7 \%$ (see Table 1 ).

Whole surface of samples is covered by oxide film after scale resistance testing; this film has various thickness: $8.8 \mu \mathrm{m}$ in average, $0.5-1.2 \mu \mathrm{m}$ as minimal thickness.

As a result of experimental data processing, the adequate mathematical relationships between hardness (HRC), scale resistance $(\Delta \mathrm{m})$ and relative wear resistance coefficient $\left(\mathrm{K}_{\mathrm{w}}\right)$ - from one side - and carbide phase parameters, such as microhardness of eutectics $\left(\mathrm{HV}_{\text {eut }}\right)$, volumetric part of titanium and niobium carbides $\left(\mathrm{V}_{1}\right)$, volumetric part of chromium carbides $\left(\mathrm{V}_{2}\right)$, length of carbides $(\mathrm{Lc})$, size of carbides $(\mathrm{Ac})$ and distance between carbides $(\Delta \mathrm{lc})-$ from other side.

Using obtained mathematical relationships and neural network program "Model", the numerical values of coef- ficients and rows of microstructure parameters influence on cast iron properties were received. Thereby, microstructure parameters were distributed in the following rows (in the order of decrease), depending on strength of influence on hardness, scale resistance and wear resistance:

$$
\begin{gathered}
\Delta \mathrm{m}: \mathrm{HV}_{\text {eut }} \rightarrow \mathrm{A}_{\mathrm{c}} \rightarrow \mathrm{V}_{2} \rightarrow \mathrm{V}_{1} \rightarrow \Delta \mathrm{l}_{\mathrm{c}} \rightarrow \mathrm{L}_{\mathrm{c}} \\
0.2780 .2050 .2040 .1830 .080 .051 \\
\mathrm{~K}_{\mathrm{w}}: \Delta \mathrm{l}_{\mathrm{c}} \rightarrow \mathrm{HV}_{\text {eut }} \rightarrow \mathrm{V}_{1} \rightarrow \mathrm{A}_{\mathrm{c}} \rightarrow \mathrm{V}_{2} \rightarrow \mathrm{L}_{\mathrm{c}} \\
0.2950 .2220 .2040 .1450 .090 .045 \\
\mathrm{HRC}: \Delta \mathrm{l}_{\mathrm{c}} \rightarrow \mathrm{V}_{1} \rightarrow \mathrm{HV}_{\text {eut }} \rightarrow \mathrm{V}_{2} \rightarrow \mathrm{A}_{\mathrm{c}} \rightarrow \mathrm{L}_{\mathrm{c}} \\
0.2830 .2590 .1920 .1620 .0970 .006
\end{gathered}
$$

\section{Conclusions}

Influence of niobium and aluminium content as well as of cooling rate on the structure, phase and chemical properties of oxide layers, wear resistance and heat resistance of cast iron was examined. It was established that:

1. Heat- and wear-resistant cast iron has the optimal special properties for the following variation of the components (mass. \%): 2.1-2.2 C; 4.5-5.0 Mn; 18.0-19.0 Cr; $1.0-1.2 \mathrm{Ni} ; 0.4-0.6 \mathrm{Ti}, 2.0 \mathrm{Nb} ; 2.0 \mathrm{Al}$. Wear resistance and scale resistance increased by 1.2 and 2.0 times respectively in comparison with cast iron ICh220Kh18G4Yu2B2NT, while growing stability parameter is equal to zero for cast iron which was cast in dry SLM.

2. Joint alloying by aluminium and niobium promotes simultaneous rise of heat resistance and wear resistance. Wear resistance increases due to enlargement of carbide phase volume; the part of $(\mathrm{Nb}, \mathrm{Ti}) \mathrm{C}$ carbides and complex chromium and manganese carbides also increases. Aluminium is included in composition of oxide films: more than $24 \% \mathrm{Al}$ is containing within the areas corresponding to austenite dendrites. It elevates protective properties of films and, respectively, scale resistance of the alloy. Joint alloying by aluminium and chromium causes secondary hardening in a casting mould, dispersed particles of $\mathrm{M}_{7} \mathrm{C}_{3}$ carbides are forming in solid form during cooling; as a result, no structure degradation occurs at the testing temperatures and growing stability increases.

3. Heat resistance and wear resistance are considered as structural sensitive properties; topography of oxidized surface and thickness of oxide film as well its chemical composition are stipulated by the structural and phase state and chemical composition of alloy phases. So, more than $24 \% \mathrm{Al}$ is containing within the areas corresponding to austenite dendrites, thereby the film which is forming in these areas is thin due to high aluminium content in it. The surface of oxide layer, which is corresponded to eutectics, is enriched by more than $65 \% \mathrm{Mn}$. In the areas which correspond to eutectics, the film is loose and its thickness increases.

4. Numerical values of the coefficients and mathematical relationships between hardness, scale resistance, relative wear resistance coefficient (from one side) and carbide phase parameters as well as rows of microstructure parameters influence on cast iron properties were determined. 


\section{REFERENCES}

1. Gushchin N. S., Kulikov V. I., Nuraliev F. A., Takhirov A. A. Wear-resistant chromium-alloyed cast iron with special properties. Liteinoe proizvodstvo, 2015. No. 4. pp. 7-11.

2. Aleksandrov M. V. Structure forming and abrasive wear-resistance of cast composite material of the system presented by alloyed cast iron and TiC. Liteishchik Rossii. 2015. No. 2. pp. 29-34.

3. Netrebko V. V. Alloying features of white wear-resistance cast iron. Lityo i metallurgiya. 2014. Vol. 75. No. 2. pp. 37-41.

4. Nofal Cmrdi A. Metallurgical aspects of white cast iron with high chromium content. Liteishchik Rossii. 2017. No. 11. pp. 26-32.

5. Silman G. I. Alloyed white iron with composite structure. Metal Science and Heat Treatment. 2005. Vol. 47. pp. 343-348.

6. Tsypin I. I. White wear-resistant cast iron - evolution and prospects. Liteinoe proizvodstvo, 2000. No. 9. pp. 15-16.

7. Bobro Yu. G. Alloyed cast iron. Moscow. Metallurgiya. 1976. 288 p.

8. Silman G. I. Thermodynamics and thermokinetics of structure forming in cast iron and steel. Moscow: Mashinostroenie. 2007.302p.

9. Garber M. E. Wear-resistant white cast iron: properties, structure, technology, operation. Moscow: Mashinostroenie. 2010. 280 p.

10. Karantzalis A. E., Lekatou A., Kapoglou A., Mavros H., Dracopoulos V. Phase Transformations and Microstructucal Observations During Subcritical Heat Treatments of a High-Chromium Cast Iron. Journal of Materials Engineering and Performance. 2012. pp. 1030-1039.

11. Sain P. K., Sharma C. P., Bhargava A. K. Microstructure Aspects of a Newly Developed, Low Cost, Corrosion-Resistant White Cast Iron. Journal Metallurgical and Materials Transactions A. 2013. Vol. 44F. pp. 1665-1671.

12. Yoganandh J., Natarjan S., Kumaresh Babu S. P. Erosive Wear Behavior of Nickel-Based High Alloy White Cast Iron Under Mining Conditions Using Orthogonal Array. Journal of Materials Engineering and Performance. 2013. Vol. 22. No. 9. pp.2534-2540.

13. Zhenting W., Hongming G. Investigation on microstructure and wear resistance of the new Cr-W-Mo-V high-alloy wear resistant cast iron. Advanced Materials Research. 2015.Vols.1061-1062. pp. 670-673.

14. Kolokoltsev V.M., Petrochenko E.V. Structure features and properties of high-alloy white irons. Vestnik Magnitogorskogo gosudarstvennogo tekhnicheskogo universiteta im. G. I. Nosova. 2013. Vol. 45. No. 5. pp. 3-8.
15. Petrochenko E. V. Features of crystallization, forming of structure and properties of wear- and heat-resistant cast iron in various cooling conditions. Dissertation for Dr. Eng. degree: 05.16.01. reported 11.12.12. approved 20.05.13. Magnitogorsk. 2012. 310 p.

16. Molochkova O. S. Choice of composition and examination of structure and properties of heat- and wear resistant complex alloyed white cast iron. Dissertation for Cand. Eng. degree: 05.16.01. reported 16.10.12. approved 10.01.13. Magnitogorsk. 2012. 123 p.

17. Goldshtein Ya. E., Mizin V. G. Inoculation of Fe-C alloys. Moscow: Metallurgiya. 1993. 416 p.

18. Kawalec M. The spheroidization of VC carbides in high-vanadium cast iron. Archives of Foundry Engineering. 2011. Vol. 11. (Spec. 3). pp. 111-116.

19. Wang Z. H., He D. Y. et all. Effect of vanadium on property of Fe-Cr-C hard-facing alloy. Transactions of the China Welding Institution. 2010. Vol. 31. No. 9. pp. 61-63.

20. Kawalec M., Corny M. Alloyed white cast iron with precipitation of spheroidal vanadium carbides VC. Archives of Foundry Engineering. 2011. Vol. 12. No. 4. pp. 95-100.

21. Gromczyk M., Kondracki M., Studnicki A., Szajnar J. Stereological analysis of carbides in hypoeutectic chromium cast iron. Archives of Foundry Engineering. 2015. Vol. 15. No. 2. pp. 17-22.

22. Kolokoltsev V. M., Petrochenko E. V., Molochkova O. S. Influence of boron modification and cooling conditions during solidification on structural and phase state of heat- and wear-resistant white cast iron. CIS Iron and Steel Review. 2018. Vol. 15. pp. 11-15.

23. Kolokoltsev V. M., Petrochenko E. V., Molochkova O. S. Al influence on the phase composition, structure and properties of heatand wear-resistant cast iron of $\mathrm{Cr}-\mathrm{Mn}-\mathrm{Ni}-\mathrm{Ti}$ system. Chernye metally. 2018. № 7. pp. 6-11.

24. Kolokoltsev V. M., Petrochenko E. V., Molochkova O. S. Effect of niobium addition on the structural-phase composition, mechanical and special properties of cast irons based on the $\mathrm{Cr}-\mathrm{Mn}-\mathrm{Ni}-\mathrm{Ti}$ system. Chernye metally. 2019. No. 2. pp. 18-24.

25. Efremenko V. G., Cheilyakh A. P., Kozarevskaya N. V., Shimidzu K., Chabal Yu. G., Efremenko A. V. Intra-phase distribution of chemical elements in the complex alloyed white cast iron. Visnik Priazovskogo derzhavnogo tekhnichnogo universitetu. Tekhnichny nauki. 2014. No. 28. pp. 89-99. 